Kadir Temurçin, Gizem Uluşar

Süleyman Demirel University, Isparta, Turkey

\title{
Analysis of Spatial Development in and Around the City of Isparta through Remote Sensing and Geographic Information Systems
}

\begin{abstract}
Remote Sensing is a method of examination used in the study of resources on earth without any physical contact. It is a method by which the characteristics of the land below are recorded from space and sky. Determining the characteristics of natural and cultural resources of earth, sustainable exploitation of these resources in the most effective ways and continuous monitoring of the changes in these resources are fundamental to being a developed country. For a sustainable land use and urbanization, data about the unstable natural environment must be collected and monitored at regular intervals, and in order to do these, Remote Sensing (RS) and Geographical Information Systems (GIS) are employed. Images obtained through RS method can be analyzed for the accurate use of the data available. This study seeks to determine the spatial development in and around the city of Isparta through digital imaging processing techniques on different satellite images which belong to different years. Images from satellites ASTER and LANDSAT; information on the quarters in Isparta and the city plan and ERDAS IMAGINE 9.1 program were used in the study. The spatial development of the city of Isparta was studied on the basis of the satellite images obtained in the years 1987, 2000 and 2010 and this study was integrated into GIS. Having analyzed how much change occurred and which way it trended, important information was collected which will be used as source for future studies to be carried out on Isparta. It was observed that while residential areas increased, amount of forested land, and agricultural areas decreased during the periods studied.
\end{abstract}

Key words: remote sensing, GIS, City of Isparta, Spatial Analysis, Land Use

\section{INTRODUCTION}

Remote Sensing (RS) and Geographical Information Systems (GIS) are technologies which have often been used recently. Remote sensing is an important means which is used in the analysis of changes which occurred in the space in time. Such innovations which have occurred in satellite technology recently have made it possible to take high resolution images. As opposed to the conventional method, which cost a lot of money and required a long time 


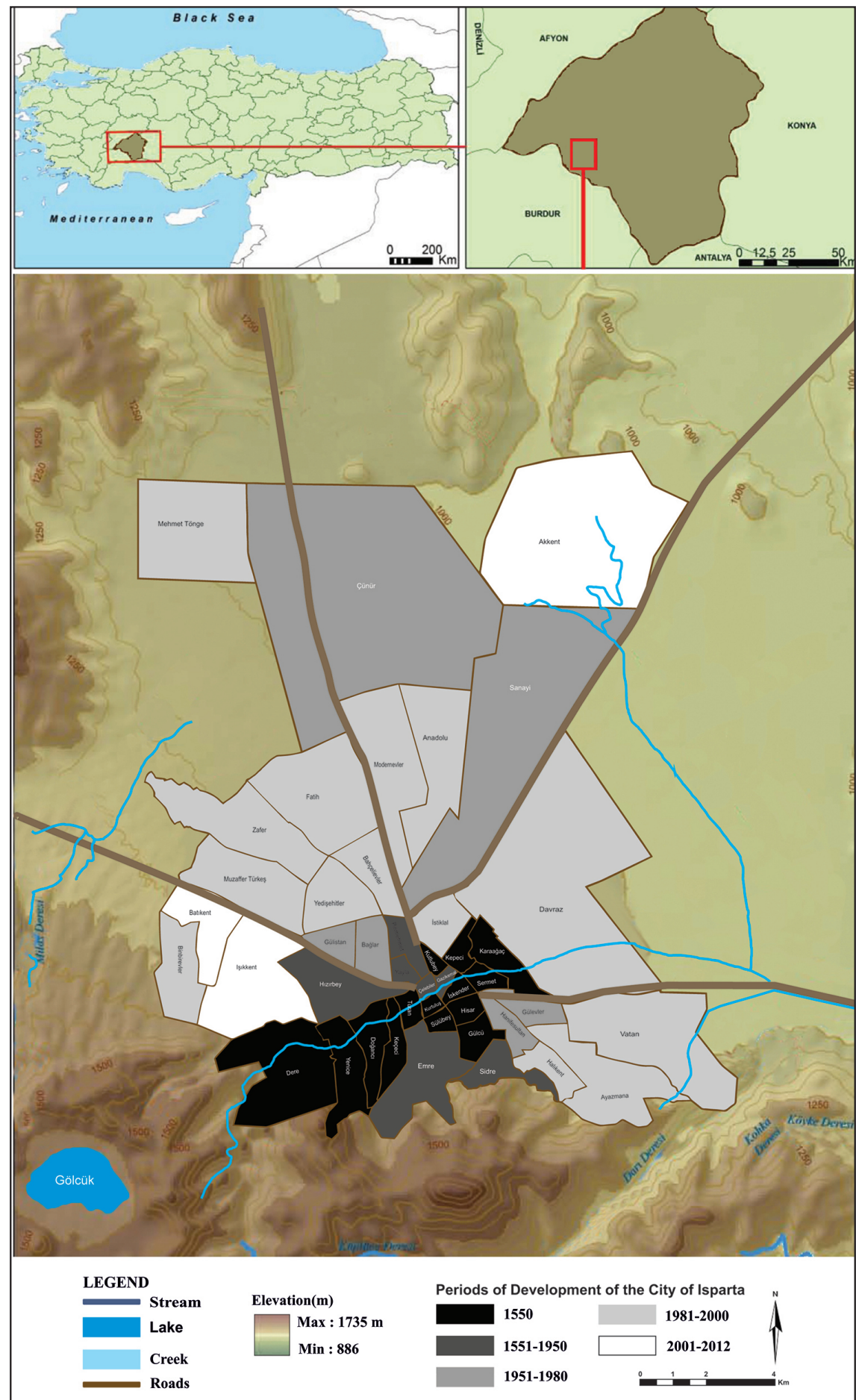

Fig. 1. The location of Isparta and historical development of its quarters 
to carry out, this new method enabled the studying and analyzing of the land to be implemented more easily and faster (Avc1, Döker 2005). Today, the way of reaching accurate and final results in a short time is only possible through proper technological support. Studies employing Geographical Information Systems and Remote Sensing for the determination spatial changes are good examples worth mentioning.

Urban development and change require a very long time to occur. In this period of development and change, the change in the structure of commercial, cultural and professional organizations renders a transformation in the spatial structure inevitable. The changes in the sectors of tourism, commerce and industry cause further changes in the physical environment to occur.

With the foundation of Süleyman Demirel University in 1992, a big change began to be seen in the residential characteristics of the city of Isparta. Increase in demands owing to the university students, who make up a considerable section the city population, those employed at the campus and the $40^{\text {th }}$ Infantry Training Command Campus has significantly affected the spatial characteristics. Consequently, new residential areas, shops and centers were opened, which caused great changes in the spatial characteristics of the city. The city of Isparta has been in a growth process in parallel with the growth of the university. In this process, the demand for more homes and spatial and economic results of this has caused a change in the physical appearance of the city. The city of Isparta is located to the north of Antalya, in the so-called Lake District in the Mediterranean Region, the place where the Central Anatolia and the Mediterranean region border each other (Fig. 1). By using Remote Sensing and Geographical Information Systems, this study seeks to determine the spatial changes in Isparta, which used to be the center of Hamitâbâd Sanjak (an administrative division in the Ottoman Empire) in the province of Konya during the Ottoman period and became a small scale city after the Republic.

\section{Data ANd Method}

In the study, the spatial development and change in and around the city of Isparta since 1970 have been analyzed through remote sensing and geographical information systems. The transformational period of the physical structure in the city has been studied by using aerial photographs, satellite images and topographical maps. For this aim, in order to determine the change in the land cover and the space, images taken by LANDSAT ETM in the years 1987 and 2000 and those taken by ASTER in 2010 were used.

Before beginning to analyze the changes, raw satellite images were processed and tailored for the actual analysis. Therefore, the relevant section of the image was cut out (creating a subset image) and then the resolutions of the images were equalized so that a problem would not occur during the change analysis.

The most common method of converting raw data into information is image classification. In this context, five land use / land cover classifications were determined. These were 
housing zones, agricultural fields, plantations, wetlands and forest pasturage land. After we had collected sample pixels from the images, a training set was created. After this, land classification was made for all the land classifications. Satellite images from Landsat and Aster taken in the years 1987, 2000 and 2010 were analyzed by employing the controlled classification method according to Maximum Likelihood algorithm and then images classified by dates were superimposed onto each other. After that process, the spatial change which was determined was mapped.

\section{The Spatial Development of the City of Isparta}

The city of Isparta, which was founded on the slopes of Akdağ (mount Akdağ), in an area where the Mediterranean region and the Central Anatolia region border each other, has expanded towards the plain of Isparta in time. The Lake District (Göller Yöresi), where the city is located, was called Pisidia in Antiquity. It is known that Isparta was founded on the site where the ancient city of Baris in Pisidia was located. The area went under the rule of the Roman Empire after Hittites, Ionians, Lydians, Persians and Alexander the Great had ruled over the area respectively. As a result of Turks' settling in Anatolia in the $13^{\text {th }}$ century, the Hamitoğulları Beyliği (Beyliks were principalities in Anatolia during the $12^{\text {th }}$ and $13^{\text {th }}$ centuries) was founded in the area.

During the Ottoman Empire, the city of Isparta was first a part of Kütahya, which was center of the General Governorship of Southern Anatolia, and later was a liva in the province of Konya. After the declaration of the Turkish Republic in 1923, it became a province center. While the city of Isparta had 17 quarters in the period prior to 1530, the number of quarters rose to 31 in 1591 (Akdemir 2008). According to the yearbook of 1882 of the province of Konya, the city of Isparta was constituted of 28 quarters. In addition, Isparta had one Armenian quarter and four Rum (Turkish Greek) quarters until the beginning of the Republic (Temurçin, Babacan 2006). In the post-Republic period, in the year 1935, the city had 24 quarters, whereas in 1980 the number rose to 27 and with the addition of 14 new quarters in two decades, the number rose to 41 in 2000 (Akdemir 2008). Today, the city is made up of 44 quarters according to the records of the municipality of Isparta. The city population, which was 18,433 in 1935 , dropped to 18,383 in 1950 . The population rose to 86,475 in 1980 and to 112,117 in 1990. Finally, by an increase of 79,976, it reached 192,093 in 2011 (Turkish Statistical Institute 2012).

The city of Isparta is surrounded by mountains in the south and west and by plains in the north and east. Since it is bordered by steep slopes in the south, it tended to expand towards the north, northwest and east. To the north of Isparta stream, along which the city of Isparta was founded, lie quarters of Turan, Çelebiler, İskender and Kurtuluş, which were the first quarters in the city, and the city started to expand towards the north and south in time. Isparta tended to spread in the then industrial area, the site around the stream, in the north and east along the highways and railway (in the direction of Antalya, Afyon and Eğirdir). 
During the years following 1970s, a significant increase was witnessed in residential areas owing to industrialization and urbanization. Within the context of a slum prevention program and housing estate, new residential areas were developed, the first of which was Gülistan quarter. During the later decades, new residential areas (housing estates) such as Davraz, Anadolu and Modernevler were built. Hallkent (to the south of the highway to Antalya), Mehmet Tönge (Bağkur Evleri) and Binbirevler (to the south of the road to Gölcük) followed these.

After 1990, Süleyman Demirel University, which was founded in the north of the city, appears to be the most significant spatial change. With the coming of the university in 1992, the changes occurred in many places in the city. New employment areas were created directly or indirectly and besides this, thanks to both spending by students and institutions, a dramatic change in the economic structure was seen. With the boost in the city population, a big demand for new housing occurred, which increased the city spatially.

\section{Analysis of the Spatial Change Through Satellite Images}

The spatial development of Isparta and its outskirts was analyzed by studying the development plans and satellite images and it was determined how much the residential areas expanded and at what stage the development was. Besides this, efforts were made in order to understand and reveal the socio-economic and socio-cultural aspects of the city. The total surface area of the studied area was 22,592.16 hectares. The areas which were classified according to the satellite images were examined in three different periods.

As a consequence of the analysis of the satellite images taken in 1987, 2000 and 2010, it was seen that: in all of the three periods, forest and pasturage land covered more areas than the others. While agricultural land came second after forest and pasturage in the years 1987 and 2000, in 2010 residential areas came second after forest and pasturage, having got ahead of agricultural land. It was observed that agricultural land, having fallen behind, came only the $4^{\text {th }}$ on the areas under study. Over the periods, it strikes the eye that there was a steady and fast increase in the residential areas, while there was a steady decrease in the surface area of the forest-pasturage and agricultural land (Tab. 1).

Tab. 1. Field Values of the Classes (classified areas) in the Satellite Images

\begin{tabular}{|l|r|r|r|r|r|r|}
\hline \multirow{2}{*}{ CLASSES } & \multicolumn{2}{|c|}{1987} & \multicolumn{2}{c|}{2000} & \multicolumn{2}{c|}{2010} \\
\cline { 2 - 7 } & Hektar & \multicolumn{1}{c|}{$\%$} & Hektar & \multicolumn{1}{c|}{$\%$} & Hektar & $\%$ \\
\hline Orchards & $3,023.21$ & 13.38 & $2,019.11$ & 8.94 & $3,383.78$ & 14.98 \\
\hline Habitation & $1,399.67$ & 6.20 & $3,130.43$ & 13.86 & $5,258.01$ & 23.27 \\
\hline Forest and Pasture & $13,220.28$ & 58.52 & $11,634.46$ & 51.50 & $11,232.88$ & 49.72 \\
\hline Water Areas & 70.86 & 0.31 & 77.34 & 0.34 & 72.54 & 0.32 \\
\hline Field Areas & $4,878.14$ & 21.59 & $5,730.82$ & 25.37 & $2,644.95$ & 11.71 \\
\hline TOTAL & $22,592.16$ & 100 & $22,592.16$ & 100 & $2,2592.16$ & 100 \\
\hline
\end{tabular}


According to the satellite image taken by LANDSAT ETM in 1987, the areas were as follows: forest and pasturage areas $-13,220.28$ ha, agricultural land - 4,878.14 ha, vineyards and orchards $-3,023.21$ ha, residential areas $-1,399.67$ ha and wetlands -70.86 ha (Fig. 2-6). According to the satellite image taken by LANDSAT ETM in 2000, the areas were as follows: forest and pasturage areas $-11,634.46$ ha, agricultural land $-5,730.82$ ha, residential areas $-3,130.43$ ha, vineyards and orchards - 2,019.11 ha and wetlands were - 77,34 ha (Tab. 1, Fig. 3-7). According to the satellite image taken by ASTER in 2010, the areas were as follows: forest and pasturage areas $-11,232.88$ ha, residential areas 5,258.01 ha, vineyards and orchards $-3,383.78$ ha, agricultural land $-2,644.95$ ha and wetlands -77.34 ha, which shows a significant change (Tab. 1, Fig. 4-8).

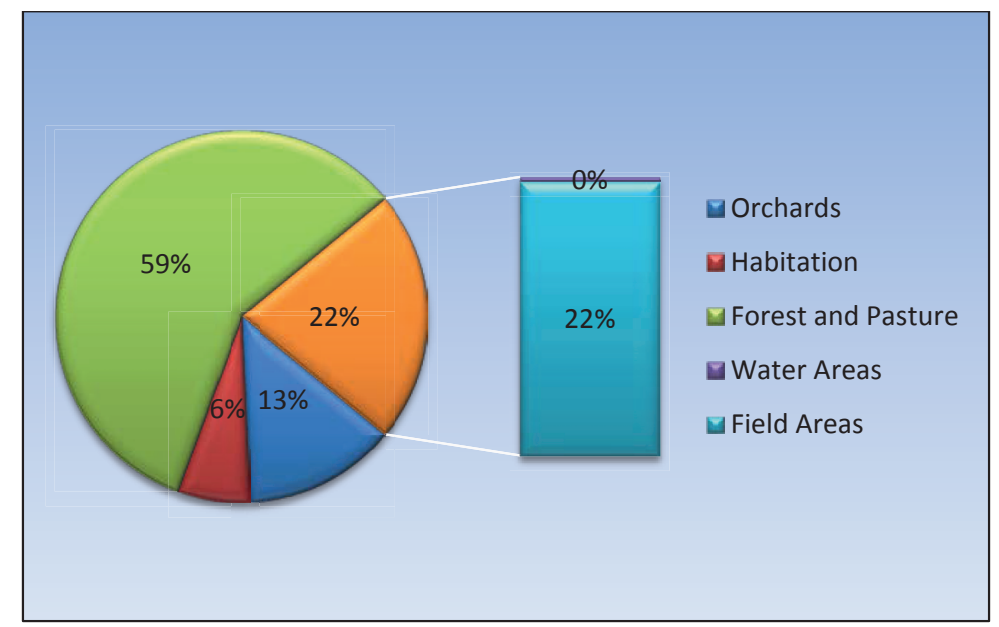

Fig. 2. Values by percentage of the classified areas in total (1987)

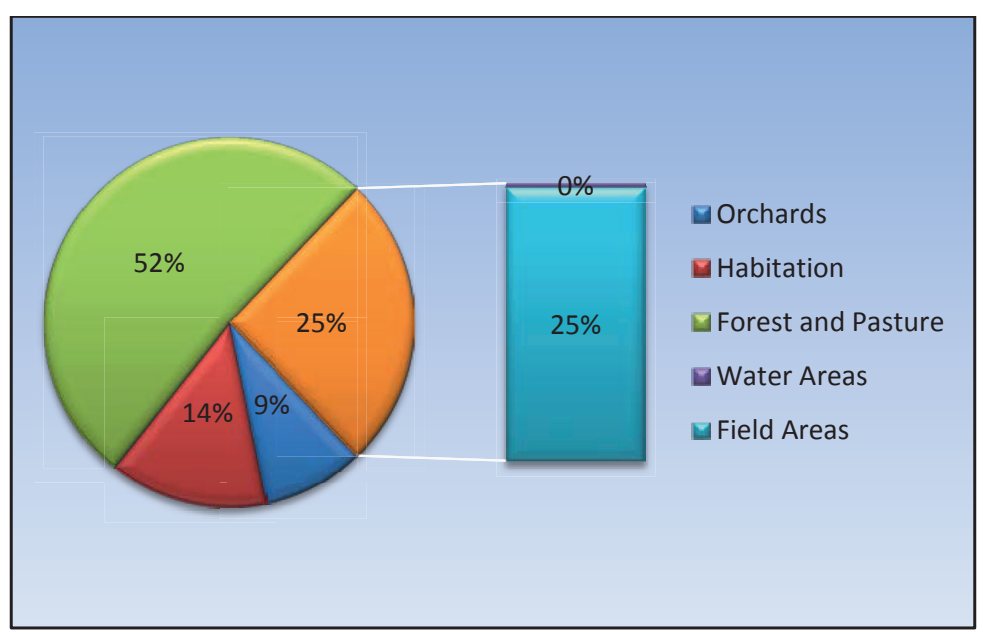

Fig. 3. Values by percentage of the classified areas in total (2000) 


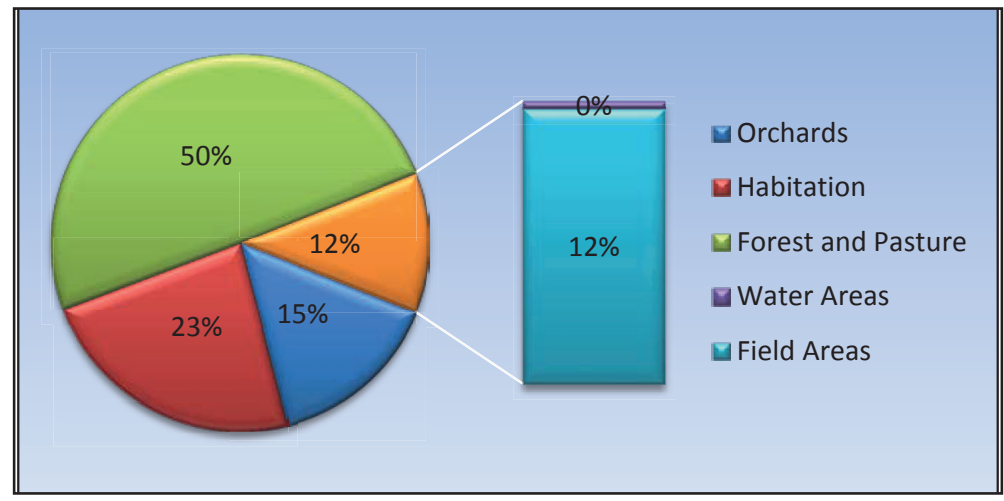

Fig. 4. Values by percentage of the classified areas in total (2010)

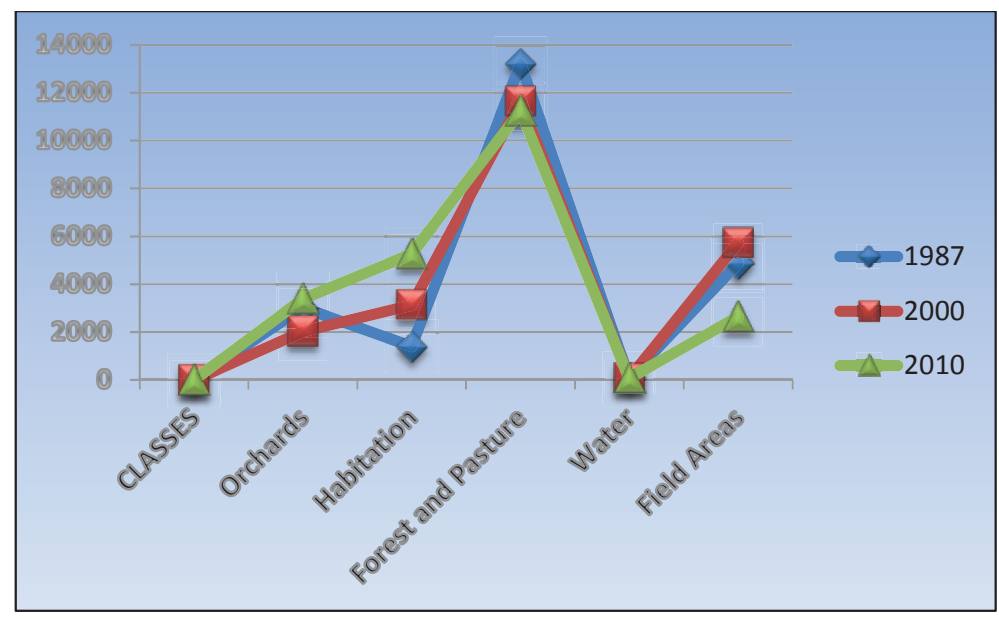

Fig. 5. Values by percentage of the classified areas in total

The biggest change happened in the residential areas and agricultural land during the classified periods. Residential areas, which covered $6.2 \%$ of the total area in 1987 , first rose to $13.86 \%$ in 2000 and then $23.27 \%$ in 2010 , reaching $5,258.01$ ha, which correspond to an increase of $3,858.34$ ha over a period a little more than two decades. With the steady expansion of residential areas, agricultural land declined in area having been lost to new housing. Agricultural land, which covered an area of 4,878.14 ha of the total area, dropped 2,644.95 ha in 2010 (Fig. 5-9).

Vineyards and orchards, which amounted to 3,023.21 ha in 1987, dropped to 2,019.11 ha, because of the fact that revenue from the vineyards and rose fields around the city declined, and as a result, people preferred to sell the land as building land. However, with the planting of more rose, apple, cherry etc. trees in the region, which are profitable agricultural products, and thanks to the improvement in the irrigation system, the area of vineyards and orchards increased to $3,383.78$ ha in 2010 . No significant change was observed in the area of the wetlands over the period. 


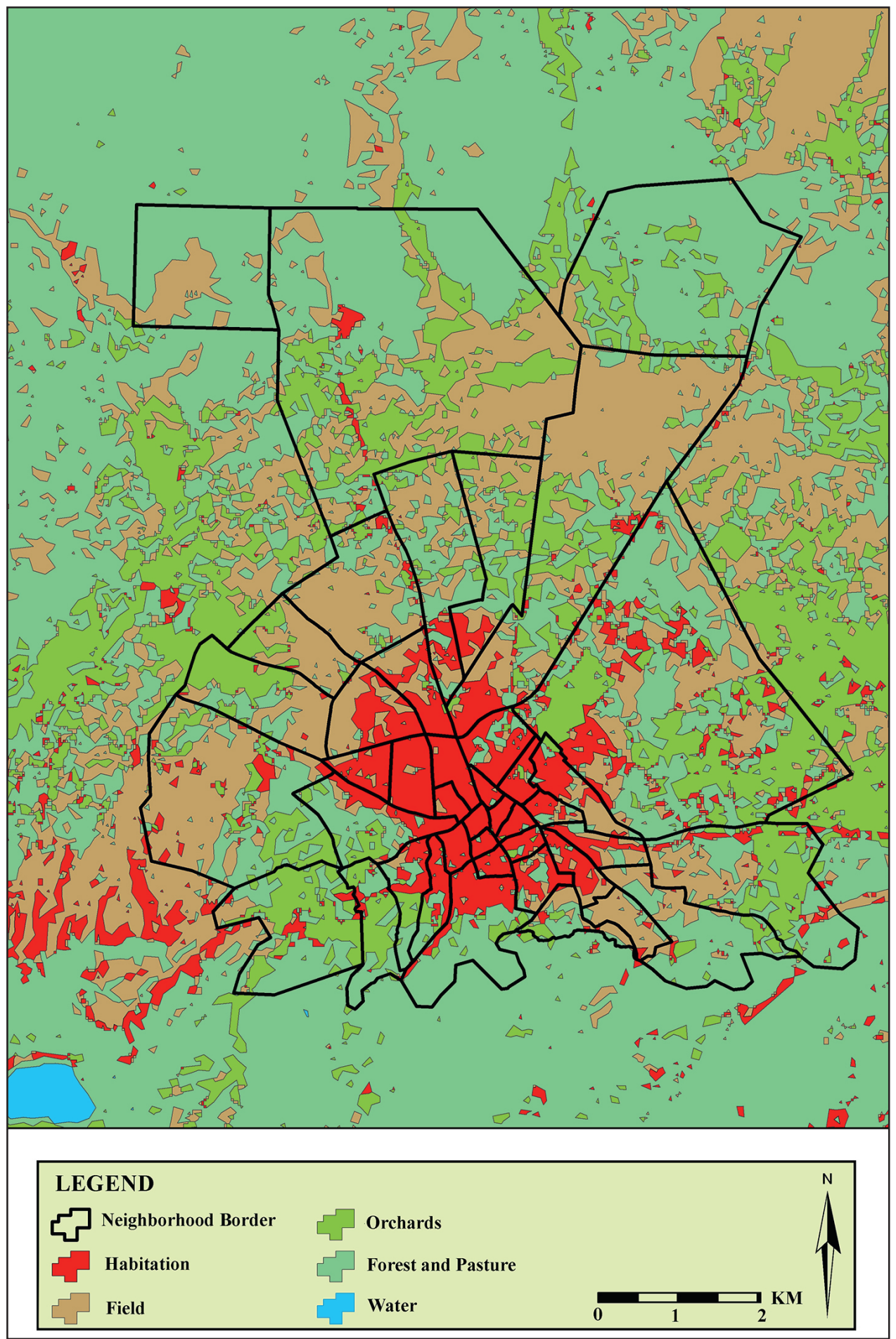

Fig. 6. LANDSAT image of Isparta, 1987 (controlled classification) 

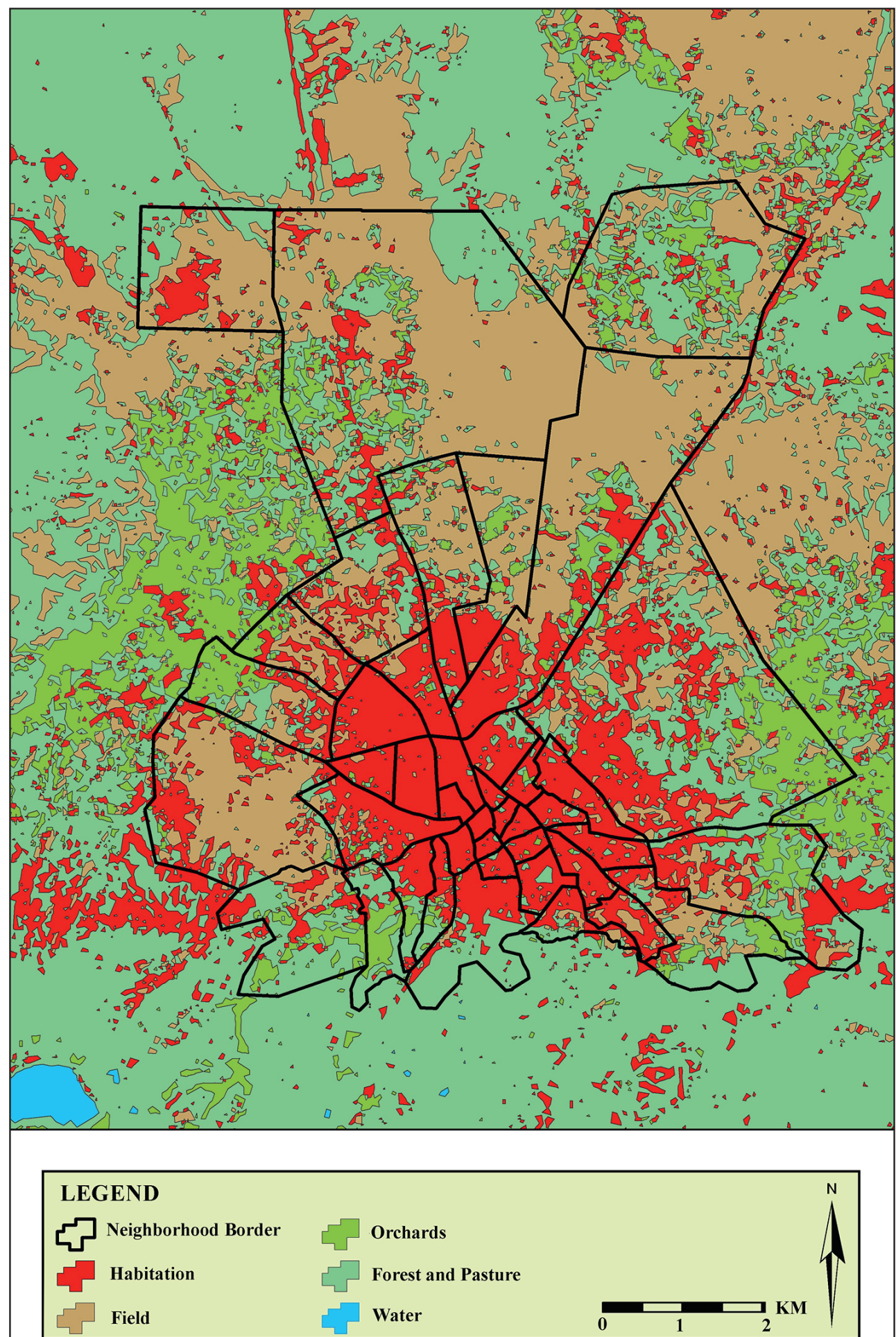

Fig. 7. LANDSAT image of Isparta, 2000 (controlled classification) 


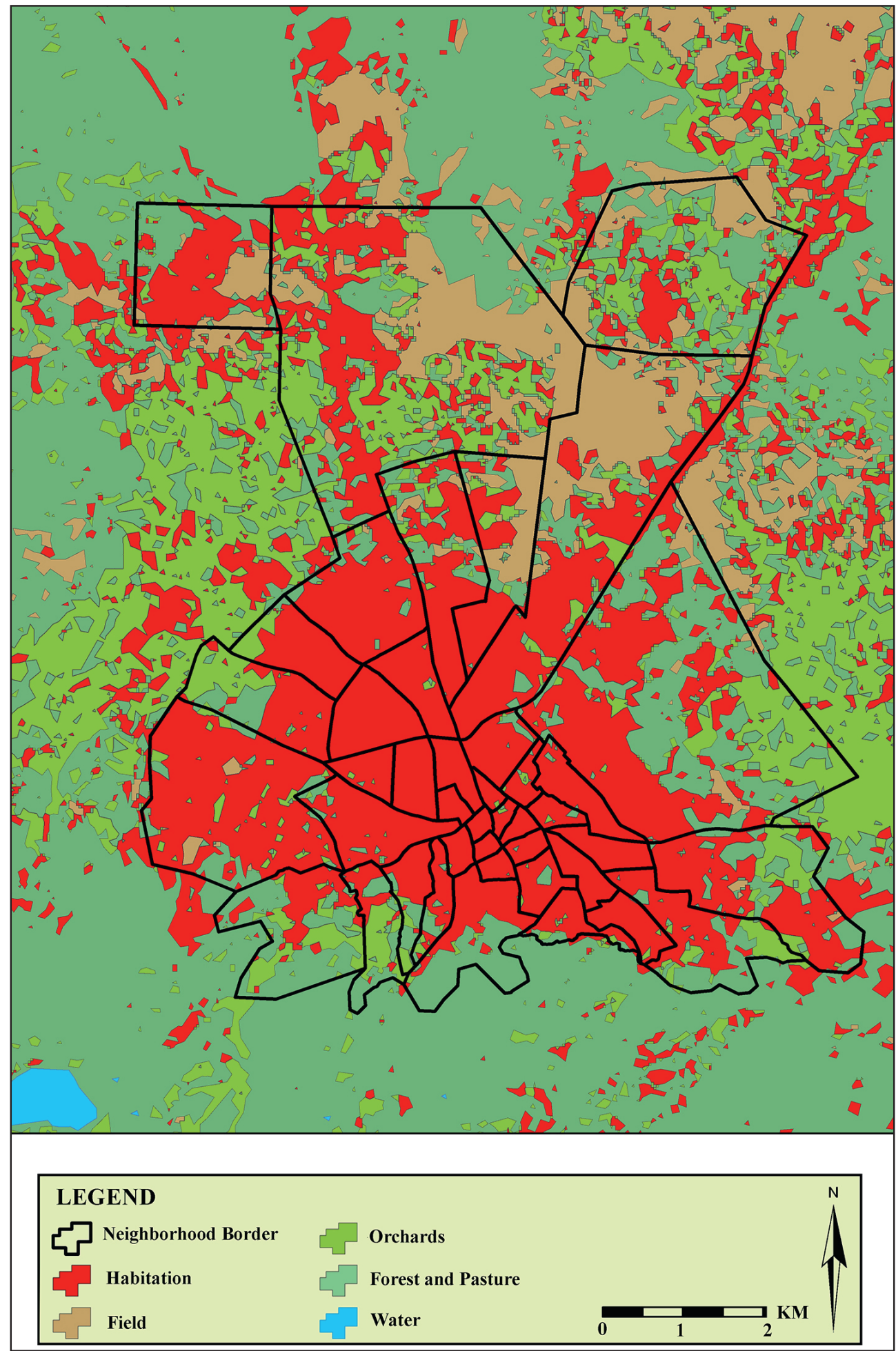

Fig. 8. ASTER image of Isparta, 2010 (controlled classification) 


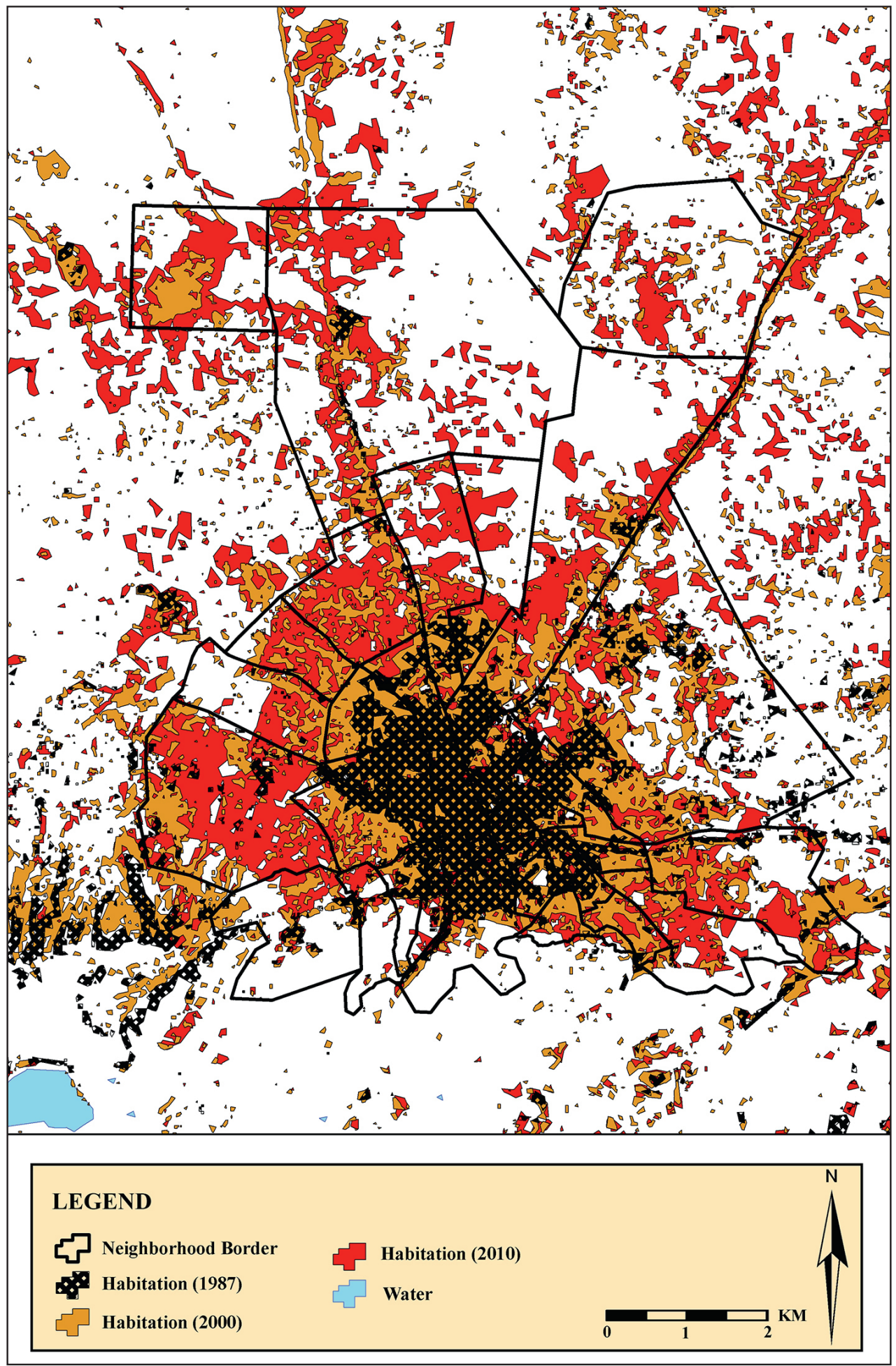

Fig. 9. Overlayed (superimposed) satellite images 


\section{Results}

To conclude, physical factors such as topography, soil fertility and streams, as well as human factors such as transportation network, slum prevention projects, housing zone projects, industry and commerce all had a considerable effect on the development and change in and around the city of Isparta and where it tended to expand. Depending on all these factors:

- Demographic developments which happened as a consequence of industrialization, urbanization and centralization brought along the changes and developments in Isparta. These developments and changes were experienced in social and economic structure as well as in physical space.

- In addition to other small scale industrial plants, tannery rose oil distillation and carpet weaving flourished after the Republic, which led to other developments such as transportation and service sector.

- In 1938, the first development plan was made and new governmental service buildings were built. With the railway coming to the city, new housing developments started, modifying the physical structure of the city. Especially from the 1950s onward, as a result of the fast increasing population, the city changed considerably, taking on new functions.

- Having analyzed the satellite images taken in 1987, 2000 and 2010, we observed that forest and pasturage covered the most area in 1987, 2000 and 2010. However, it was also seen that while the residential areas increased steadily, forest and pasturage declined over the same period. The demand for new housing rose owing to the industrialization and urbanization of the city; therefore, slum prevention and new housing projects were planned and carried out in the south and east of the city in order to meet this demand. The city expanded along the highway to Antalya in the east, along the road to Gölcük in the west and along the highway to İstanbul in the north.

- With the foundation of Süleyman Demirel University in 1992, the spatial development expanded increasingly towards the north. As a result of the population increase, the demand for new housing rose, which accelerated the spatial growth.

- Generally, urban development happened in accordance with the development plans.

\section{References}

Akdemir, S. (2008). XVIII. Yüzyılın İlk Yarısında Isparta: Sosyo-ekonomik ve Kültürel Hayat, Isparta: Isparta Valiliği İl Kültür ve Turizm Müd. Yay.

Aksu, F. (1944). Isparta'nın Mahalle Adları Üzerine Bir Araştırma. Ün Dergisi, C.XI/123-124, 17151718 .

Arıkan, Z. (1988). XV-XVI. Yüzyıllarda Hamit Sancă̆g. İzmir.

Aster Satellite Image (2010). VNIR 15 Metre Spatial Resolution.

Avcı, S., Döker, F. (2005). Ömerli Havzası-İstanbul'da Mekânsal Değişimin Uzaktan Algılama Metodları İle Belirlenmesi. Ege Coğrafi Bilgi Sistemleri Sempozyumu Bildiriler Kitabı. İzmir.

Başbakanlık Osmanlı Arşivi. Konya Vilayet Salnameleri (1877, 1982, 1992). Ankara.

Başbakanlık Osmanlı Arşivi. Temettuat Defteri (1844). İstanbul. 
Böcüzade, S.S. (1983). Kuruluşundan Bugüne Kadar Isparta Tarihi. Serenler Yayınevi. İstanbul. Çetin, S. (2011). Dönüşüm Süreçlerinin Tarihi Kent Merkezleri üzerine Etkileri: Isparta Örneğinde Bir İnceleme, Erciyes Üniv. Fen Bil.Enst. Dergisi, V.27, I.2., 185-199.

Emecen, F. (1999). Isparta. DİA, C.XIX, s. 194-200. İstanbul.

Harita Genel Komutanlığı (1983). 1/25000 Ölçekli Topografya Haritası (M25a4). Ankara. Isparta Belediyesi (2012). İmar Verileri, İmar Müd. Isparta.

Isparta Belediyesi (2012). Isparta Şehri İmar Planı. İmar Müd. Isparta.

Landsat Satellite Image (1987). TM 30 Metre Spatial Resolution.

Landsat Satellite Image (2000). ETM 30 Metre Spatial Resolution.

Temurçin, K., Babacan, H. (2006). IXX. Yüzyılın İlk Yarısında Isparta Şehrinin Sosyo-Ekonomik Yapısı ve Gayri-Müslimler. Atatürk Kültür Merk. Erdem Dergisi, S. 45-46-47, 155-182.

Temurçin, K. (1998). Isparta Şehri. İstanbul Üniv.Sos.Bil.Enst. Yüksek Lisans Tezi, İstanbul.

Temurçin, K. (2004). Isparta İli Ekonomik Coğrafyası. Ankara Üniv. Sos.Bil.Enst. Doktora Tezi, Ankara.

Türkiye İstatistik Kurumu (2012). TUIK Adrese Dayalı Nüfus Kayıt Sistemi Nüfus Verileri. Ankara.

Yıldırım, Ü., Kılıç, F. (2006). Uzaktan Algılama Yöntemleri ile Afyonkarahisar'ın Şehirsel Gelişsiminin İzlenmesi. Fatih Üniv. 4. Coğrafi Bilgi Sistemleri Bilişim Günleri, İstanbul.

Kadir Temurçin, assoc. prof. dr., Süleyman Demirel University, Arts and Sciences Faculty, Department of Geography.

Dr. Kadir Temurçin, was born in Isparta/Turkey in 1973. He graduated from Istanbul University, Faculty of Arts, Department of Geography in 1995. He received an MA degree in 1998 at the University of Istanbul "Isparta City" and a PhD degree in 2004 at the University of Ankara "Isparta Province Economic Geography". An assistant professor since 2005, associate professor since 2011. He has been working as an academic at Süleyman Demirel University, Faculty of Arts and Sciences since 1998. He has been working as an academic in the field of economic geography, history, geography, tourism geography, geography of crime. He published one book (Geography of Crime in Turkey - City Public Security Crimes), known in the field of geography journals, published two articles in Poland and Canada, and presented in two papers international symposiums. This research studies the original analysis of the spatial distribution of crimes in Turkey. Historical geography studies, in Lakes Region about the health and social geography one book (Sıhhiî - İçtimâî Geography) and about non-Muslims characteristics of the socio-economic structure and population two article in the $19^{\text {th }}$ century during the Ottoman Empire. In addition, in another study, the spatial aspect of change in provision of public services in rural areas and in particular to assess the impact of migration reveals that public services in rural areas. He devoted some of his other works to different fields in Turkey: industrial geography, tourism geography, energy resources, urban geography, population and migration. In total, more than 30 academic who has studied Dr. Kadir Temurçin, focused academically in the field Crime of Geography and Historical Geography. Assoc. prof. Dr. Kadir Temurçin is married and has one child.

Gizem Uluşar, MA, Süleyman Demirel University, Faculty of Arts and Sciences, Department of Geography.

Gizem Uluşar was born in Kumluca/Turkey in 1988. She graduated from Süleyman Demirel University, Faculty of Science and Literature, Department of Geography in 2010. She started doing her MA degree in 2010 at the University of Süleyman Demirel.

adres/address: Süleyman Demirel University,

Arts and Sciences Faculty, Department of Geography,

32260 Çünür/Isparta, Turkey

e-mail: kadirtemurcin@sdu.edu.tr (Kadir Temurçin),gizemulusar10@gmail.com (Gizem Uluşar) 